\title{
Computadores: super-heróis ou vilões?
}

\author{
[SILVA FILHO, J o „, J osuÈ da. FlorianÛpolis: UFSC, Centro de \\ Cíncias na EducaÁ,o, N`cleo de PublicaÁıes, 2000. 200 p.]
}

Karla I sabel de Souza* e Sérgio Ferreira do Amaral ${ }^{* *}$

Este trabalho é um estudo realizado com crianças e professores, para levantar as possibilidades pedagógicas do uso da informática na Educação Infantil.

0 tema central é a construção de conhecimento no uso de informática na Educação, tendo o professor como mediador e os softwares como ferramentas. O s assuntos abordados e analisados demonstram a importância do tema na contemporaneidade.

A Educação Infantil é o foco, mas o livro é uma boa leitura para educadores de todos os níveis de ensino, pois discute educação, comunicação e novas tecnologias. Serve de guia para educadores dessa área, apresentando comentários sobre vários softwares, e também pode ser utilizado como modelo para outros educadores que precisem pensar o uso de softwares ou da informática em seu campo de atuação.

Como afirma M aria Luiza Belloni na apresentação do livro:

0 autor busca mostrar que é preciso ter clareza de que os computadores são ao mesmo tempo heróise vilões, em todas as situações em queascriançasosutilizam, queelesestão no mundo delas, fazem partedo universo de socialização, pelo menos para aquelasquetêm acesso aestastécnicas. Para as outras, osmilhões decrianças brasileiras excluídas, a escola públicaéaúnica viade acesso a estas 'máquinas maravilhosas', sendo estaarazão principal para sua integração à educação (Belloni, p.11).

A primeira parte da obra discute se computadores são prejudiciais à educação infantil, chegando à conclusão de que é preciso ficar atento às oportunidades

\footnotetext{
* Doutoranda e pesquisadora do Lantec - Laboratório de Novas Tecnologias aplicadas à Educação da FE-Unicamp. karla@unicamp.br

* * Professor do Departamento de Ciências Sociais na Educação (Decise) e Coordenador do Lantec - FE-Unicamp. amaral@unicamp.br
} 
oferecidas sugerindo um cuidado com propostas inconsistentes. Também conta a história do reconhecimento da Educação Infantil. Relata que apenas em 1989 houve um reconhecimento da sociedade, com relação a os direitos da infância ${ }^{1}$.

Ainda atenta para a sociedade atual, muito influenciada pela comunicação de massa, com transformações aceleradas, em que a tecnologia tem papel mediador, além de ser fruto das mediações. A mediação referida é a "mediação generalizada", que é a relação que cada indivíduo tem consigo, com outros e com 0 mundo.

Essa mediação generalizada éque estabeleceos parâmetros de uma nova cultura, quepassamos a chamar decomunicacional, em cujo contexto os meios de comunicação são as tecnologias mais ostensivas, embora não sejam asúnicas presentes (p.49).

A segunda parte detalha a pesquisa de campo, na qual se podem observar as circunstâncias do desenvolvimento da pesquisa e a discussão da linha teórica adotada. Para o autor, a participação de professores foi fundamental, principalmente para que pudesse realizar um diagnóstico de conceitos e de representações acerca do uso pedagógico da informática.

A primeira constatação é a de que existe a necessidade de haver investimento em formação de professores, para que estes possam ampliar seu domínio sobre os computadores e os programas. A proposta feita ao grupo de formação professoras que estavam envolvidas na proposta - foi a de construir conhecimento:

considerando que, ao concluir suas próprias apresentações, 0 sujeito aprende a antecipar estratégias de soluções para seus problemas, a planejar seus passos e a refletir mais sobre os procedimentose os produtos que executou (p. 59).

A participação de crianças no laboratório de informática também proporcionou algumas observações. U ma delas diz respeito às experiências que possuíam. 0 mesmo grupo de crianças foi disposto em três grupos diferentes: o primeiro era composto por crianças que não sabiam usar o mouse, mas tinham familiaridade com o computador, apesar de não possuí-lo em casa. 0 segundo grupo, minoria, reunia crianças que dominavam o mouse e outras ferramentas e possuíam computador em casa. 0 último grupo era formado pela maioria das

1. A Convenção Internacional sobre Direitos da Infância redigiu 54 artigos voltado relativo aos compromissos que a sociedade atual deve assumir com relação às crianças. No Brasil, iniciou-se o debate sobre a versão preliminar do Referencial Curricular Nacional para a Educação Infantil (MEC/SEF/COEDI, 1989). 
crianças, que não sabiam usar o mouse e não tinham informações sobre 0 computador.

Aplicativos e softwares foram usados nas tarefas, e os objetivos das atividades são claros no livro:

aprender a lidar com o ambienteinformatizado na presençade crianças, ha de aproveitar pedagogicamente esse espaço e de como articulá-lo ao conjunto de atividades outras já desenvolvidas normalmenteno espaço das préescolas (p. 69).

D epois dos estudos com o grupo de formação, o autor estabelece uma linha de raciocínio em relação à Educação Infantil com o uso pedagógico da informática. A primeira constatação é a de que não se separa o "cuidar" do "educar"; a segunda diz respeito às experiências de vida, afirmando que "cada ser humano entra em contato com o ambiente e a cultura construída coletivamente, socialmente; acumula experiências; seleciona as mais significativas para si e descarta as que considera indesejáveis" (p. 74).

0 autar revela preocupação com o excesso de valorização de um tipo de conhecimento que se convencionou chamar de científico. Embora reconheça a importância deste na sociedade contemporânea, relata pesquisas que demonstram que, devido a esse descompasso, principalmente a Educação Infantil tem enfrentado situações desastrosas. Por isso, reforça a necessidade de desenvolver estratégias de trabalho, visando o uso pedagógico da informática com as crianças.

$\mathrm{N}$ a seqüência, o texto trata dos problemas gerados quando se tenta agregar 0 trabalho pedagógico com informática. Escolher equipamentos (hardwares) até mesmo um bom equipamento de multimídia -, softwares e referências em língua portuguesa é uma dificuldade que os educadores enfrentam.

A pesquisa fez um cadastro de softwares, buscando definir a categoria (idade a que se destina), a descrição (do que trata o jogo), os objetivos, o conteúdo e os recursos de que eles necessitam para funcionar. Também foram realizados testes com os softwares: o primeiro buscou analisar a interface (questões de usabilidade); o segundo buscou examinar a qualidade educativa do software; o terceiro, determinar o "preconceito"e avaliar valores presentes nos softwares.

Por fim, o texto fala dos limites e das perspectivas da pesquisa. Q uanto à capacitação do docente, afirma que não se pode priorizar a instrumentalização e que o importante é haver um "esforço no sentido de propiciar uma vivência coletiva de práticas educacionais alimentadas pela reflexão acerca das situações vivenciadas" (p. 103).

Sobre o uso do computador na sala de aula são expostas várias perguntas e respostas, que buscam apontar os prós e os contras do uso da informática. 0 
livro traz um posicionamento sério e embasado em pesquisa, o que faz o leitor refletir sobre 0 assunto.

Ainda há, anexa ao livro, uma lista de softwares com comentários, que poderá ajudar quem está buscando mais informações sobre o tema. 